\title{
Kompleksitet i velfærdsstatens frontlinje
}

\section{Signe Mie Jensen \& Kaspar Villadsen}

Med afsæt hos frontmedarbejderne og lokale ledere i en kommunal velfærdsinstitution undersøger vi de ledelsesmæssige konsekvenser af øget kompleksitet opstået gennem en række samvirkende faktorer, herunder de sidste to årtiers indførelse af nye styringsteknologier inspireret af New Public Management og frygten for skandalisering blandt hjemmeplejemedarbejdere i udføreleddet. Fokus er på relationen mellem leder og de fagprofessionelle, og kernespørgsmålet er, hvilke hidtil oversete udfordringer, de aktuelle ledelsesbetingelser stiller frontlederen overfor i dennes relation til frontmedarbejdere.

$\mathrm{D}$ enne artikel er baseret på akademisk følgeforskning foretaget $\mathrm{i}$ forbindelse med et ledelsesudviklingsforløb i Tønder Kommunes hjemmepleje. Konklusionerne af forskningen blev første gang præsenteret på FOA's lederkonference i 2012. Efter oplægget blev vi kontaktet af en pædagog, som leder en klynge af pædagogledere i Købehavn. Han fortalte, at de udfordringer og problematikker, som oplægget udpegede, var meget lig dem, pædagogerne kæmpede med i hans klynge i København. Han havde blot manglet en måde at forklare og tydeliggøre problematikkerne over for sin faggruppe, så de kunne adressere dem. Pædagogen bad os om at holde samme oplæg for pædagogerne i København. Her vakte konklusionerne fra projektet vedrørende hjemmehjælpere i Tønder ganske rigtig resonans blandt pædagogerne. Denne umiddelbare genklang tydede på, at vores iagttagelser har en bredere relevans for velfærdstatens professioner, og det udgør nøglemotivationen for denne artikel.

Artiklen undersøger, hvordan det påvirker ledere og deres medarbejdere i velfærds- statens udførerled, når kompleksiteten af de krav, der stilles til dem, øges. Nøglespørgsmål inkluderer:

1. Hvorledes kan lederne få blik for de udfordringer, som kompleksiteten skaber for medarbejdernes arbejde, når de selv er en del af denne kompleksitet?

2. Hvilke former for ledelse bliver der behov for i sådan et felt?

3. Hvordan kan lederen udnytte medarbejdernes faglighed til både at få blik for 'skjulte' udfordringer samt håndtere dem på en inddragende måde?

Disse spørgsmål søger artiklen at komme med nogle bud på med afsæt i den konkrete case fra Tønder Kommunes hjemmepleje. Konklusionerne bygger på deltagerobservationer af et ledelsesudviklingsforløb igangsat af fagforeningen FOA i samarbejde med Tønder Kommune, udført af en konsulent fra firmaet SundUddannelse (senere Previa Sundhed) i fire af Kommunens seks hjemmeplejeenheder. Forløbet strakte sig over et halvt år og involverede særligt de lokale 
afdelingsledere (herefter frontledere), men også den centrale ledelse, tillids- og arbejdsmiljørepræsentanter samt social- og sundhedshjælpere og -assistenter (medarbejdere). Projekt Velfærdsledelse skulle udforske ledelse af velfærdsservices ved at følge et forløb til forbedring af ledelsesprocesserne på en kommunal arbejdsplads.

Observationsforløbet var ikke styret af forud givne antagelser om et modsætningsforhold mellem eksempelvis regler og faglighed, eller at New Public Management har fastlåst medarbejderne $\mathrm{i}$ rutiner og skabt krydspres etc. Vi efterstræbte en åben tilgang til vores empiri - herunder især, hvorledes deltagerne i forløbet opfattede deres arbejdsforhold og ledelsesbetingelser.

Allerede inden projektets officielle start, blev vi opmærksomme på, at frontledere og medarbejdere brugte begrebet 'civil ulydighed' som en positiv betegnelse for situationer, hvor medarbejdere handlede ud fra deres faglighed frem for, hvad reglerne foreskrev. Dette opfattede modsætningsforhold mellem regler og faglighed viste sig at have stor indflydelse på faciliteringen af plejeydelser og udgør en langt større udfordring for frontlederne, end parterne var opmærksomme på inden projektets start. Derfor blev dette et centralt fokus, efterhånden som forskningen tog form.

På basis af observationerne påviser vi, at frontlederen eksisterer $i$ et spændingsforhold mellem systemkrav og det forhold, at de er ledere af fagprofessionelle med specifikke faglige normsæt. Sådanne 'frontlinjebureaukrater' må ofte finde egne måder at afveje de forskellige hensyn, der trænger sig på, i behandlingen af den specifikke borger. I denne forstand foregår leveringen af velfærdsydelser i et 'krydspres' (Lipsky 2010). Analyserne i artiklen undersøger de forskellige fortolkninger, som henholdsvis ledere og de fagprofessionelle medarbejdere har af deres arbejdsbetingelser og faglige udfor- dringer, der rekurrerer omkring en modstilling mellem regler og faglighed. Iagttagelser fra feltarbejdet præsenteres i form af fire temaer:

Under det første tema, 'polyfonisk pres', redegøres der for det krydspres, lederen udsættes for. Presset centrerer sig især om behov for at mediere mellem velfærdsprofessionelles normer for omsorg og kvalitet i arbejdet og krav om overholdelse af en række formelle standarder, f.eks. for tid, økonomi og rapportering. Dette afsnit udforsker også udviklingen inden for styring af velfærdsservices generelt i løbet af de seneste to årtier og tilbyder hermed en bredere forståelsesramme for den efterfølgende analyse.

Det andet tema, 'civil ulydighed', beskriver den centrale modstilling mellem de økonomiske og lovgivningsmæssige krav og omsorgsfaglige/professionelle værdier. Det analyseres, hvorledes 'civil ulydighed' er opstået som et positivt ladet begreb blandt ledere og medarbejdere og $\mathrm{i}$ forlængelse heraf, hvordan medarbejderne fremstiller brugen af deres faglighed som legitim, men 'ulovlig'.

Afsnittet om sprogforskelle, artiklens tredje tema, undersøger frontlederens og de fagprofessionelles forskellige virkelighedsopfattelser, og hvorledes disse skaber udfordringer for lederne. Det illustreres bl.a. ved, at lederen som følge af krydspres må aktivere flere kommunikative koder: den juridiske, den økonomiske og en omsorgskode, mens de fagprofessionelle primært kodificerer informationer og krav igennem omsorgskoden.

Endelig, for det fjerde, 'lederens moderne udfordringer'. Her sammenfattes de ledelsesmæssige udfordringer, som studiet udpeger. En central udfordring for lederen er bl.a. at legitimere fagligheden blandt de fagansatte ved at skabe rum for italesættelse af løsninger udviklet 'nedefra'. 


\section{Metode i casestudiet}

Konsulenten i ledelsesudviklingsforløbet anlagde en semi-struktureret tilgang, da hun lod deltagerne bidrage til at forme diskussionerne og aktiviteterne. For at få deltagerne til at italesætte temaer på spil i feltet, benyttede konsulenten sig af tre temaer: 'kvalitet og effektivitet', 'trivsel og arbejdsglæde' og sidst 'kreativitet og nytænkning'. Hvad gav kvalitet og effektivitet? Og hvad forhindrede samme? Dette var blandt de mange spørgsmål forankret i de tre temaer, der ansporede ledere og ansatte til italesætte deres arbejde og gav konsulenten materiale at arbejde med. Prioritering blev desuden et nøgletema i løbet af projektet. Forløbet omfattede en række workshops, supervision i de enkelte afdelinger, interviews af ledere og repræsentanter, facilitering af afdelingsmøder samt seminarer.

Signe Mie Jensen var observatør ved 12 aktiviteter, hvilket udgør cirka halvdelen af aktiviteterne i udviklingsforløbet. Således er der tale om struktureret feltarbejde, men dog struktureret af konsulenten og ikke observatøren (Kristiansen \& Krogstrup 1999, 47-48). I alle tilfælde var der tale om observation af informerede informanter. Når det ikke var muligt for forfatterne at deltage, blev de orienteret af konsulenten ved møder, telefonisk og skriftligt.

Vi supplerede vores observationer med centralt materiale om undersøgelsesfeltet, herunder kommunens folder om Kvalitetsstandarder for personlig pleje og praktisk hjoelp (Tønder Kommunes Social- og Sundhedsforvaltning 2011); oversigt over 'pakkerne', som er en model, der benyttes til at fastsætte modtagernes plejeydelser; orienteringsbrev om udviklingsforløbet til lederne osv.

\section{Niklas Luhmanns blik for forskelle}

Luhmanns iagttagelsesbegreb er grundstenen for bearbejdning af observationerne $i$ denne artikel, hvorfor vi her giver en nærmere bestemmelse af dette. Iagttagelse karakteriseres af Luhmann som en forskelssættende operation (Luhmann 1993, 485), der kløver verden i to - en positivt markeret plusside versus en umarkeret refleksionsside - eksempelvis ret/uret, betale/ikke-betale, læring/ikke-læring etc. Man kan ikke iagttage eller kommunikere om noget uden at markere den ene side af en forskel (Andersen 2000, 74). Dog er iagttagelser ikke bundet til subjekter, men snarere til kommunikationssystemer. Det er antagelsen, at kommunikationsdeltagere ofte ikke er i stand til at iagttage den forskel, hvormed de iagttager. Når vi således observerer kommunikationen blandt lederne og deres medarbejderne i Tønder Kommunes hjemmepleje, får vi blik for både, hvad de markerer i deres iagttagelser, samt hvad de ikke markerer, men som alligevel indgår i den fortløbende kommunikation som en refleksionsside. De følgende analyser viser, hvordan disse grundantagelser skaber blik for en række ledelsesudfordringer, som ellers næppe var kommet i fokus.

Det andet hovedperspektiv, som vi henter i Luhmanns systemteori, er tesen om det moderne samfunds funktionelle differentiering (Luhmann 1977, 39). Det økonomiske system, det pædagogiske system, sundhedssystemet osv. er eksempler på disse funktionssystemer. Tilknyttet funktionssystemerne er symbolsk generaliserede medier. Disse medier er generelle, fordi de kan danne medie for en hvilken som helst kommunikation (Andersen 2002, 29). Eksempelvis er mediet for det økonomiske system penge. Medierne er symbolske, fordi de skaber betydning omkring et specifikt symbol. Når kommunikation formes i et bestemt medie, har det konsekvens for, hvad der videre kan kommunikeres og hvilke valgmuligheder, der sættes for de involverede kommunikationsdeltagere. 
Når kommunikationen aktiverer et symbolsk generaliseret medie, eksempelvis mediet penge, opdeles verden i to, såsom betale/ikke betale (Luhmann 1993, 485). Hermed kan verden kun iagttages igennem denne kode i det givne øjeblik. En beslutning, der tages i mediet penge, bliver en økonomisk beslutning vedrørende prioritering af ressourcer, modsat f.eks. en pædagogisk eller retslig beslutning (Andersen 2002, 28). Målet med analysen er ikke at påpege forekomsten af et specifikt medium, men snarere at undersøge nøjere hvilke former for kommunikation, der konkret kan udfolde sig, når et bestemt medium formes.

Organisationssystemer, eksempelvis velfærdsinstitutioner, besidder ikke egne medier og koder, men kobler sig på de funktionelle systemers logikker. Et hospital vil således arketypisk koble sig på sundhedssystemet, fordi det her finder sit rationale for problemløsning, og det er igennem den binære kode sund/ikke sund, at hospitalet løbende processerer information og bestemmer, hvad der hører til i henholdsvis hospitalet og dets omverden.

Der er ingen hierarkisk relation mellem funktionssystemerne. Der er i det moderne samfund intet 'overfunktionssystem', ingen metakoder og derfor intet endegyldigt kriterium for at afgøre, om eksempelvis en økonomisk betragtning er bedre end en retslig eller en pædagogisk (Andersen \& Born 2003, 185). Samtidig er der i mange tilfælde sket en slags eksplosion, hvor de medier, der tidligere var bundet til et bestemt funktionssystem med dets specifikke institutioner, nu dukker op i en række nye sammenhænge. Et eksempel er den udbredte tale om 'den lærende organisation' og 'livslang læring', som indikerer, at det pædagogiske medium har delvist løsrevet sig fra sit konventionelle ophav. Udviklingen betyder, at stadig flere organisationer bliver polyfone (Andersen 2008a, 48-50). Polyfoni betyder, at der er en flerhed af tilslutningsmuligheder i en given organisatorisk kommunikation, hvilket skaber situationer præget af uafgørbarhed. I dag skal et hospital f.eks. ikke længere blot helbrede. Det skal også tage ansvar for sine medarbejderes konstante videreuddannelse (pædagogisk kodning) og helst være konkurrencedygtig over for privathospitaler (økonomisk kodning). Kravet om at være i stand til at oscillere mellem flere funktionslogikker må antages at være særligt stort for velfærdsorganisationer, idet velfærdsstaten har påtaget sig at levere services, der løser en mangfoldighed af problematikker produceret i forskellige funktionssystemer.

\section{Polyfonisk pres}

Lederne af de fagprofessionelle er placeret $i$ en situation, hvor de skal kunne lede ud fra deres faglighed (her omsorgssystemet). Samtidig skal de i deres ledelse tage økonomiske hensyn (det økonomiske system) og være opmærksomme på at overholde de retslige bestemmelser (retssystemet). Denne situation med til tider konflikterende hensyn betegner feltet selv som 'krydspres'. Lipskys (2010) tese om krydspres handler om frontarbejdere i velfærdsinstitutioner, som forventes at tage den specifikke person i betragtning i sagsbehandlingen. Strukturerne omkring deres arbejde forhindrer imidlertid dette, idet der kræves prioritering af ressourcer og kategorisering af klienter for at indpasse dem i organisationens tilbud og regulativer. Andersens (2002, 35-36) begreb om organisatorisk 'polyfoni' betoner sameksistensen af konflikterende fordringer i mere generel forstand - en polyfoni, der synes at være blevet intensiveret igennem det sidste årtis reformer af den offentlige sektor, herunder: strukturreformen, velfærdsreformen, globaliseringsreformen, kvalitetsreformen osv. (Pedersen 2008, 9). Vi skal i det 
følgende kort se på, hvordan disse modsatrettede krav er blevet beskrevet i relation til velfærdsproducerende institutioner.

Iagttagere af velfærdsreformer har beskrevet, hvordan politiske ønsker om at 'få mere velfærd for pengene' har affødt indførelse af en række teknologier til at sikre større (økonomisk) effektivitet og gennemsigtighed i velfærdsproduktionens processer. Disse teknologier er blandt andet udtrykt i intensiveret overvågning, evaluering, dokumentation og budgetansvar, samt øget sammenligning af serviceydende enheder (Pedersen 2008, 29). Sideløbende med denne øgning af central kontrol blev reformerne båret frem af ønsker om decentralisering af ansvar, deregulering og mere selvledelse i de lokale serviceenheder. Disse ønsker blev fremsat i en anerkendelse af, at de erfaringer og den faglige viden, der skal sikre kvalitet, findes på gulvet i disse enheder. Decentraliseringen skulle "frisaette frontmedarbejderens kreative og faglige potentialer" (Majgaard 2009, 267). Lederne skulle derfor ikke længere nøjes med at forholde sig til faste juridiske eller professionelle rammer, men være i stand til at afkode, udfordre og udvikle varierende sæt af mål og værdier (Pedersen \& Hatley 2008, 327). Dette tildelte umiddelbart større autonomi til de lokale enheder. Men med det ekstra ansvar til kommunerne og frontlederne kom også et større ansvar for at dokumentere og kontrollere, hvad den nye autonomi blev anvendt til.

Således er rammerne for denne selvledelse ikke blevet dereguleret, men snarere re-reguleret med krav om bl.a. øget selvovervågning (Majgaard 2009, 267; Pedersen 2008, 339). Dette skaber paradokser imellem kontrol og selvstyring samt central ledelse og decentral ledelse, hvilket er paradokser, der præger frontledernes hverdag (Majgaard 2009, 283; Thygesen 2009, 8).

Pointen med denne redegørelse er at sandsynliggøre, at der er sket en intensi- vering af den kompleksitet af ofte svært forenelige $\mathrm{krav}$, der stilles til lederne i de yderste velfærdsled (Pedersen 2008, 29-31; Jensen 2009). Det er således en udfordring for frontledere, der som i Tønder Kommunes hjemmepleje i højere grad end tidligere må kommunikere i både en omsorgskode, en økonomisk og en retslig kode. Ofte skal de forme beslutninger i situationer, hvor en ideel balance ikke er mulig (Andersen 2002, 43). Dette er ikke unikt for Tønder Kommunes hjemmepleje (Jensen 2009, 16). Eksempelvis identificerer Majgaard - i sin artikel om krydspres i Odenses børne- og ungeforvaltning - økonomi, ret og faglighed som kolliderende logikker, der sætter lederen under pres (Majgaard 2009, 278). Tilsvarende demonstrerer Villadsen i sin analyse af 'udslusning' af hjemløse de udfordringer, der opstår i kraft af sameksistensen af forskellige koder i de involverede organisationers kommunikationen om hjemløse (Villadsen 2011). Tesen om en forøgelse af kompleksitet i ledelsen af velfærdsorganisationer vil bidrage til belysning af en helt central observation i vores studie, nemlig eksistensen af 'civil ulydighed' i hjemmeplejen.

\section{Civil ulydighed i hjemmeplejen}

Vi stødte tidligt på begrebet 'civil ulydighed' i feltet. På et møde mellem to repræsentanter for FOA, de centrale ledere fra afdelingen Pleje \& Omsorg, konsulenten og kommunens uddannelseskonsulent fortalte en af de centrale ledere, at 'civil ulydighed' af visse ledere og medarbejdere blev sidestillet med at bruge sin faglighed. Faglighed betragtedes som tilladelse til at benytte sin sunde fornuft, være kreativ og komme med professionelle skøn i individuelle situationer ud fra den faglighed, som man har opnået fra sin uddannelse og erfaring. Desuden blev fagligheden kædet tæt sammen med omsorg, og brugen af faglighed blev si- 
destillet med den 'rigtige form for omsorg'. Det kom ofte til udtryk ved, at medarbejderne mente, at ydelserne skulle udformes på baggrund af personlig, faglighed vurdering fremfor reglerne. En medarbejder sagde på en stor fællesworkshop:

"Man skal have mere indflydelse på baggrund af personlig vurdering af borgerens situation."

En del af medarbejdere opfattede ikke lovkravene og andre nedskrevne regler om ydelser til borgeren som befordrende for udøvelsen af deres faglighed og dermed ikke som garant for omsorg. I medarbejderens optik var lovkravene, regler og anden retsligt kodet kommunikation en fremmed reference i forhold til deres faglighed. Det systemteoretiske perspektiv gjorde os i stand til at observere, at medarbejderne kløvede det ulovlige i henholdsvis en legitim ulovlighed og en reel ulovlighed. På den måde er civil ulydighed opstået som et positivt begreb, der henviser til den 'rigtige form for omsorg', der har fundet sted, når man har handlet ud fra et fagligt skøn om, hvad borgeren havde brug for, men som stred imod reglerne. Under et interview italesatte en leder forbindelsen mellem civil ulydighed og faglighed:

"Jeg har det godt med, at mine medarbejdere er lidt ulydige, f.eks. at køre ned efter en liter moelk. De må gerne toenke selv og bruge deres faglighed. Men jeg vil gerne vide det, så hvis nogen ringer og siger, at de har set en hjemmehjoelper i Kvickly, så kan jeg bakke min medarbejder op. Hvis vi kan argumentere for, hvad vi gør, er der aldrig nogen, der kan komme efter os."

Under et andet interview brugte en arbejdsmiljørepræsentant samme lovløshedskommunikation i relation til pakkerne, som er et værktøj til at fastsætte omfanget og indholdet af ydelsen til borgeren:

"Det, der er dumt ved pakkerne, er, at der er et spring fra 32 til 120 minutter, så man må lege Robin Hood og tage lidt rundt omkring."

En medarbejder sagde i begyndelsen af forløbet:

"Jeg føler mig begroenset af alle de regler. F.eks. må man ikke følge borgerne ned til bageren i stedet for at gøre rent."

På en kvalitetsworkshop kom denne modsætning mellem faglighed og regelstyring til udtryk i form af bekymring for disponatorerne, som vurderer borgerens behov:

"Disponator er som en lus mellem to negle. Skal man overholde pakken, eller skal man vaere loyal over for sin faglighed?"

Det er umiddelbart paradoksalt, at retsprincipper og regler sættes på ydersiden af omsorgskoden, da netop lovgivningen har til formål sikre betingelserne for udøvelse af omsorg. Den konstitutive konsekvens af dette paradoks er, at der konstant skabes en konflikt mellem rettens og omsorgens logikker.

I beskrivelsen af omsorgssystemet pointerer Sverre Moe (Moe 1998, 46-61), at ingen andre systemer har kompetencen til at bestemme omsorgsbehov. Imidlertid kobler det politiske system sig til retssystemets medium, loven, i sit forsøg på at bestemme behov og styre omsorgsydelserne. Noget tyder på, at denne kobling har været med til at skabe en irritation, der har gødet jorden for plejepersonalets begreb om omsorg som civil ulydighed. Principielt anerkender hjemmehjælperne legaliteten i den retsligt fastsatte omsorg, men ikke kvaliteten, som de mener kun kan sikres gennem deres faglighed. 
Ledernes og medarbejderne opfattelse af, at fagligheden er under pres, bekræftes af Hanne Marlene Dahl, der argumenterer for, at kommunikationen omkring hjemmehjælpere som fagprofessionelle er forsvundet helt gennem det sidste årti. I stedet kommunikeres der om dem som værktøjer, leverandører, udføreleddet osv. (Dahl 2012, 150-154). Beslutningskompetencen for udformningen af omsorgen er kommunikativt blevet flyttet fra hjemmehjælperne til staten, kommunen og den ældre selv (Dahl 2012, 144).

Desuden kan der her iagttages en spænding (som er generel for velfærdsinstitutioner) mellem det partikulære og det universelle (Villadsen 2011); medarbejderne ønsker at bruge deres faglighed til at handle med afsæt i den individuelle borger og ser partikulære hensyn som en del af deres faglighed. Love, regler og standarder, der gennem det sidste årti er kommet større vægt på (Dahl 2012, 145), kan kun i begrænset omfang tage udgangspunkt i den individuelle borger i kraft af deres universalisme, og når de kobles med ambitioner om sammenlignelighed og etablering af 'best practice', sker der en forskydning mod standardisering og væk fra partikulære hensyn. Dette er ligeledes et spændingsfelt, hvor medarbejderne iagttager en udfordring af den faglige omsorg.

Det er ikke kun den retslige logik, der bidrager til kompleksiteten og medarbejdernes opfattelse af den øgede udfordring af deres faglighed. Kommunikation formet i den økonomiske kode er også blevet mere præsent, både pga. frontledernes større økonomiske ansvar og i endnu højere grad med den alment anerkendte tematik om den offentlige sektors krise samt finanskrisen. Fordi kommunikation i den økonomiske kode har en tendens til at installere en knaphedslogik i kommunikationen, blev mindre økonomisk råderum blandt medar- bejderne og lederne sidestillet med mindre tid til den rigtige omsorg:

En tillidsrepræsentant udtrykte dette under et supervisionsmøde:

"Der mangler tid hos borgerne. Man føler ikke altid, man får giort tingene ordentligt, fordi der kun er et kvarter til det."

En medarbejder sagde på en workshop:

"Der er ikke tid til de svage. Der er ikke tid til omsorgstid. Man spørger ikke, hvordan det går, for man har ikke tid til at tage sig af det, hvis borgeren begynder at groede."

Opfattelsen af de stramme økonomiske rammer var konstant i forløbet. Adspurgt på et ledelsesseminar, hvad der optog lederne mest for tiden, udtalte en frontleder:

"Økonomien. Alt er så økonomistyret, det er svoert at få det hele til at hoenge sammen."

På en workshop for ledere, arbejdsmiljø- og tillidsrepræsentanter sagde en frontleder:

"Det er ikke behovsstyret - det er økonomistyret." En anden tilføjede dertil: "Det er politisk styret."

Både medarbejdere og frontledere udtrykte gennemgående en opfattelse af, at der før i tiden havde været bedre plads til omsorgen, hvilket bekræfter antagelsen om, at kompleksiteten i udførerleddet er blevet øget. En arbejdsmiljørepræsentant sagde:

"Før havde man lidt mere tid. Nu hvor der er mindre tid, er der super meget fokus på at nå det, man skal [...] Vores adfoerd i dag er proeget af rutiner, regler og vaner."

En medarbejder sagde på en workshop: 
"Før kunne man bede om ting og få dem, hvis man kunne begrunde, hvorfor man har brug for dem."

\section{Skandaliseringsfrygt}

Meget tyder desuden på, at kompleksiteten er blevet intensiveret i kraft af det sidste årtis skandalehistorier i massemedierne. Medierne har tilbagevendende berettet om sager fra plejehjem og i hjemmeplejen, hvor plejere øjensynligt har gjort private ærinder i deres arbejdstid eller behandlet borgere nedværdigende. Selvom ingen af historierne har omhandlet Tønder Kommune, er hjemmeplejerne meget bevidste om risikoen for skandalisering (Kristensen 2010, 15). Eksempelvis fortalte en frontleder under et interview, at en af plejerne havde købt en chokoladebar på en tankstation, da han tankede sin hjemmeplejebil. Det skete kort efter en omtalt skandalehistorie om en plejer i København. Nogle unge mænd fik opfattelsen af, at han brugte sin arbejdstid på at købe chokolade og havde råbt ad ham og kastet med sten.

Lederen påpegede, at selvom de meget sjældent oplever den slags episoder, er det noget, plejerne tænker over. En anden frontleder fortalte, at de har stor opmærksomhed på ikke at gøre noget eller skrive noget i journalerne, der ikke kan tåle en avisoverskrift.

\section{Regeloverfortolkning og mistillid}

Tidligt i forløbet blev det klart, at der blandt medarbejderne var en tendens til regeloverfortolkning, som vores analyse tyder på har rod i øgningen af kompleksitet. Regeloverfortolkningen har desuden styrket ledernes og medarbejdernes 'behov' for at bruge begrebet 'civil ulydighed' til at legitimere faglige handlinger. Overfortolkningen havde flere varianter: Sommetider turde medarbejderne ikke handle ud fra andet, end hvad der stod i regler og tjeklister. Andre gange handlede de ud fra forestillede 'regler' og myter om forbud, der faktisk ikke var nedfældet nogen steder.

Ofte kredsede medarbejdernes kommunikation omkring udsagnet: "Vi er begroenset af regler". En følelse af mistillid til medarbejderens faglighed synes bidragende til denne udtalte frygt for at træde uden for reglerne. Øget granskning af deres arbejde igennem dokumentionskrav og regulering opfattede de som mistillid til deres arbejde (Hildebrandt 2013), hvilket genkendes fra den offentlige sektor generelt (Thygesen 2009, 8; Jensen 2009, 18). Den brede antagelse blandt medarbejderne var, at detailstyringen var iværksat, fordi der var mistillid til dem:

"Der er manglende tillid. Man skal pensle alt ud og kende de rigtige ord for at få de rigtige ting."

"Der mangler tillid. Vi vil ikke gøre mindre, vi vil faktisk gerne gøre mere. Ellers var vi ikke i det her job."

Det politiske systems strategi om decentralisering gør det svært nøjagtigt at identificere kilden til mistilliden. Ansvaret for metoden for og udførelsen af målene om kvantificering, målbarhed, resultattydelighed og økonomisk gennemsigtighed er i en vis grad lagt ud til frontlederne (Pedersen 2008, 33; Hildebrandt 2013). Således bliver kilden til den opfattede mistillid svær at finde og dermed svær at adressere. Frontlederne står derfor overfor en udfordring i forhold til at udvise tillid til deres medarbejdere, således at disse stoler på, at der er tillid til dem og deres faglighed.

Et eksempel på en myte om forbud er en medarbejder, som troede, at man ikke må koge et æg til borgeren. Medarbejderen begrundede antagelsen med, at man ikke længere måtte lave varm mad til borgerne, fordi de nu får mad udefra, som blot 
skal anrettes. Og fordi man ikke måtte lave varm mad, må man antage, at man ikke må bruge komfur, kasserolle og lignende til tilberedelse af varm mad. Altså, lød ræsonnementet, må man ikke koge et æg.

Indledende i udviklingsprojektet blev der flere gange sagt: "Det må vi ikke" eller "Jamen, det må vi jo ikke", hvortil lederne ofte svarede: "Jamen, det står der da ikke nogle steder, du ikke må". En arbejdsmiljørepræsentant citerede sig selv for at have sagt til en kollega: "Hvorfor siger du, at det må du ikke? For det må du jo godt."

Som eksemplerne viser, var det især medarbejdergruppens arbejdsgange, der var præget af myterne. Udviklingsforløbet tydeliggjorde myterne for lederne. Særligt den centrale ledelse i pleje- og omsorgsadministrationen blev overrasket. Visse frontledere havde allerede kendskab til regeloverfortolkninger, men blev i forløbet forbavset over omfanget. En frontleder sagde f.eks.:

"Folk har svoert ved at forstå, at de godt må gøre noget, der ikke står på papiret."

En bemærkelsesværdig form for regeloverfortolkning var handlen på basis af ikkeeksisterende regler. Under forløbet kom det f.eks. frem, at mange medarbejdere anså det at rede borgerens seng om morgenen som et krav. Morgenvagten er den vagt på dagen, hvor de ansatte ofte har mest travlt og derfor med fordel kan lade ikke-presserende opgaver ligge til en af de senere vagter. Desuden er det af sundhedshensyn bedst at vente med at rede sengen, til dynen er blevet kold, fordi det reducerer risikoen for husstøvmider. Alligevel fandt visse medarbejdere det magtpåliggende at rede sengen om morgenen. Bidragende til mytedannelsen var skandaliseringsfrygten:

"Hvad ville den pårørende ikke toenke, hvis hun kom forbi, og sengen ikke var redt?"
"Folk har svoert ved at lade ting ligge, som ellers ikke er livsnødvendige, af frygt for at naboen kommer ind [...] De pårørende har fokus på det, der ikke er."

For visse ansatte var overholdelse af reglerne (inkl. myterne herom) et slags skjold mod skandaliseringsrisikoen. Hvis man havde gjort alt på tjeklisten, var der i hvert fald ikke nogen, som kunne komme efter én. Effekten af de mange regler, myter og dokumentationskrav var ifølge medarbejderne, at deres arbejdsdag prægedes af regler og rutiner. Dette mindskede rummet for faglige skøn, hvilket forringede oplevelsen af kvalitet i deres arbejde markant.

Udover at regeloverfortolkningen resulterer i uhensigtsmæssige rutiner, kan den øge risikoen for overpleje, hvilket netop udpeges som en generel udfordring i den danske hjemmepleje (Mandag Morgen 2013, 12). Medarbejderne oplevede, at rutinen og frygten for ikke at leve op til reglerne førte til situationer, hvor medarbejderen hjælper borgeren med ting, denne godt kan selv. En tillidsrepræsentant gav et eksempel:

"Der var en, der havde voeret $i$ bad, og jeg begyndte helt automatisk at give ham trøjen på. Så sagde han tørt, at det kunne han da godt selv."

En anden havde oplevet, hvordan overplejen havde begrænset borgerens eget initiativ:

"Jeg spurgte engang en borger: 'Hvad vil du have til morgenmad?' Han svarede: 'Jamen, din kollega har skrevet det ude i den blå bog'."

Denne analyse skal ikke nødvendigvis ses som en kritik af de sidste 10-20 års reformering af velfærdsinstitutionerne. Men den tydeliggør, at en række konstitutive kon- 
sekvenser ved reform-implementeringen i udføreleddet er oversete og kræver yderligere belysning og refleksion. Hermed står lederne over for både muligheder og udfordringer. Men inden vi når frem til diskussionen af disse, skal vi runde endnu et aspekt, som vort fokus på forskellig kodet kommunikationen har udpeget.

\section{Sprogforskelle}

Analysen af den polyfoni, som lederne må navigere i, danner afsæt for en diskussion af en modsætning mellem lederens og medarbejdernes kommunikation og virkelighedsopfattelse.

Som beskrevet er lederne i vidt omfang nødt til at navigere polyfont pga. den øgede kompleksitet. Det kan derimod diskuteres, hvorvidt medarbejdergruppen i lige så høj grad er polyfon i sin kommunikation. Vi så tidligere, at når medarbejderne eksempelvis refererede til økonomi, kommunikerede de logikken igennem omsorgsmediet. I denne iagttagelse tolkes økonomilogikken som værende en trussel mod omsorg og derfor som et element, der ikke hører til inden for medarbejdernes meningsgrænse. Eksempelvis efterlyste medarbejderne på en workshop "mere fokus på pleje og omsorg og mindre fokus på økonomi". Adspurgt til, hvad de ønskede mindre af, svarede de bl.a. "at øonomien fylder hverdagen".

At være bevidst om den økonomiske kode er ikke det samme som at lægge den til grund for sin kommunikation. Når medarbejderne kommunikerede om deres iagttagelser af økonomi, så det ud til, at de ret entydigt iagttog økonomien som en trussel mod det, deres kommunikation og beslutningstagen refererer til: omsorg. Det er med baggrund i disse iagttagelser, at vi fremfører en hypotese om, at medarbejdernes kommunikation er overvejende homofon modsat deres lederes kommunikation, som er polyfon. Med homofon menes, at deres kommunikation i udgangspunktet formes i ét medie, nemlig omsorg.

Når medarbejderne iagttager borgerne, iagttager de dem ganske entydigt som medie for omsorg. Økonomiske krav fortolkes igennem omsorgsmediet, hvorved medarbejderne fortolkede dem som en rent kvantitativ indskrænkning af arbejdets kvalitative indhold:

"Der er ikke tid til de meget svage. Der er ikke tid til omsorgstid."

\section{"Der er for lidt borgertid."}

\section{"Er omsorgstiden blevet vaek?"}

At lederen overvejende kommunikerer polyfont, mens dennes medarbejdere kommunikerer homofont er en udfordring, fordi lederen ikke nødvendigvis er opmærksom på, at dennes kommunikation kan rammes af manglende eller negativ anknytning. F.eks. kan henvisninger til det retslige grundlag for hjemmehjælpsydelser integreres i medarbejdernes kommunikation som en truende begrænsning, snarere end som en sikring af borgerens ret til omsorg.

Manglen på gensidig anknytning pga. 'sprogforskelle' kan endvidere bidrage til risikoen for modstand mod nye initiativer og forandringer i en forandringsudsat sektor, idet medarbejderne tenderer til at anskue forandringer, der kommer udefra (eller oppefra) som trusler imod deres faglighed. Dog har lederne inden for velfærdsproduktion i udgangspunktet den styrke, at de ofte deler faglig baggrund med deres medarbejdere. De er således i stand til at kommunikere med afsæt i det samme reservoir af begreber som medarbejderne. Ledernes udfordring er imidlertid at gøre sig bevidst om, at de har integreret nye koder, som deres medarbejdere ikke umiddelbart kan 
knytte an til, og overveje, hvorledes de kan bygge bro mellem de forskellige kommunikative rationaler.

\section{Frontlederens moderne udfordringer}

Den stramme økonomiske ramme, som lederne og medarbejderne oplevede sig begrænsede af, bliver næppe mindre stram i fremtiden. Selvom der politisk tales om afbureaukratisering og tillidsreform, giver disse løfter ikke løsninger på frontlederens udfordringer i den nuværende situation.

I lyset af vore analyser foreslår vi derfor, at en central ledelsesmæssig udfordring er at understøtte og (gen)legitimere medarbejdernes faglighed - med nødvendig hensyntagen til den retsligt fastsatte ramme og det økonomiske råderum. I denne kontekst, hvor opfattelsen er, at stramheden $i$ retskravene og økonomien ikke levner plads til faglighed og kreativitet, er én mulighed at anlægge en kommunikativ strategi, der tager som præmis, at de stramme rammer betyder, at man netop er nødt til at bruge sin faglige kreativitet. Hermed kommunikeres et imperativ om, at lederen og medarbejderne både må lære at imødekomme krydspresset og skabe plads til, at der kan udvikles metoder, som på én gang udspringer af det gældende retslige-faglige kodeks og er praktisk effektive. Hertil kræves, at lederen kommunikerer behovet for kreativ innovation gennem medarbejdernes faglighed og for udbredelse af virksomme arbejdsmetoder udviklet 'på gulvet'.

En sådan innovation og kommunikation om nye løsningsmodeller bør kunne opnå tilslutning hos både lederen og medarbejderne, selvom parterne anskuer verden ud fra forskellige kommunikative rationaler. F.eks. formåede konsulenten under forløbet at skabe meningsfulde koblinger mellem ledelsesgruppen og medarbejdergruppen.
Hun udpegede hermed muligheden for en ledelsespraksis, som i mindre grad drejer sig om at implementere krav og styringsredskaber 'oppefra' i omsorgsarbejdet og i stedet betoner skabelse af anknytningsmuligheder mellem de usammenlignelige kommunikationslogikker. 'Strukturelle koblinger' er ifølge systemteorien ikke et spørgsmål om, at to systemer bringes $i$ harmoni eller i 'forståelse med' hinanden. Luhmanns begreb 'strukturel kobling' søger derimod at forklare, hvordan to systemer kan blive 'forstyrrede' af hinanden på trods af, at de begge er lukkede omkring deres selvreferentielle kommunikation. Generelt kan to systemer blive strukturelt koblede, når deres processer tillader gensidige påvirkninger eller irritationer at forekomme. Strukturelle koblinger opstår i tilfælde, hvor "et autopoietisk system er betinget af et andet autopoietisk systems komplekse ydelser, når det kan behandle dem, som om de er dele af dens eget system" (Luhmann i Seidl \& Becker 2006, 21). Principielt set er der ikke tale om, at et system (eksempelvis medarbejderne) åbner sig for et andet systems rationaler (ledelsesgruppen). Hvad der imidlertid kan forekomme, er fælles temaer, som begge systemer kan kommunikere om, uden at deres grænser opløses.

I sådanne tilfælde kan systemerne operere ud fra en forestilling om, at de enige om, hvad der kommunikeres om og iagttages. Dette fænomen er blevet benævnt 'produktive misforståelser' (Andersen 2008b, 79), hvor der med 'produktiv' menes, at nye kommunikationsmuligheder opstår i kraft af 'misforståelsen' om fælles enighed og iagttagelsesmåde. Under udviklingsforløbet formåede konsulenten at formulere temaer, som kunne fungere som en art koblingsmedier. Dette skete ved, at konsulenten satte særlige temaer på dagsordenen, bl.a. under workshops, som muliggjorde en relativt gnidningsfri oscillation mellem koderne omsorg, ret og økonomi. 
Forløbet affødte en række ledelsesmæssigt relevante opdagelser og implikationer. På ledernes foranledning handlede forløbet og arbejdet med disse temaer i høj grad om at blive bedre til at håndtere det pres, de er underlagt som følge af de forskelligartede krav, som rettes mod omsorgsarbejdet fra ekstern side. Over for medarbejderne blev forløbet især præsenteret som en vej til at effektivisere arbejdsgangene og forbedre medarbejdertilfredsheden ved at rydde ud i regeloverfortolkning og 'lovliggøre' brugen af faglighed. Igennem begreber som 'prioritering', som var afledt af temaet om 'kvalitet og effektivitet', blev der sat fokus på regeloverfortolkningen. Det blev også betonet, at fagligheden skal bruges for at kunne prioritere og komme med løsninger på, hvordan man undgår uhensigtsmæssigt skarpe prioriteringer fremtvunget af de økonomiske og retslige krav. At bruge fagligheden til at finde nye løsninger blev ligeledes formuleret igennem temaer som 'kreativitet og nytænkning'. Således søgte konsulenten, set fra en systemteoretisk optik, at mobilisere åbne og flertydige begreber, som kan genkendes af flere forskellige systemer og produktivt irritere systemerne og potentielt åbne for ny kommunikation.

For medarbejderne og lederne i Tønder Kommunes hjemmepleje skabte det desuden en sneboldeffekt, at konsulenten bag udviklingsprojektet skabte et rum, hvor man talte om, hvad man var utilfreds med i sin hverdag, hvad man var tilfreds med, hvad man godt kunne tænke sig blev ændret osv. Denne grundigere italesættelse af opgaveløsning, der netop gav et ophold fra den daglige opgaveløsning, åbnede op for erfaringer, der hidtil ikke havde været en del af fælleskommunikationen mellem lederne og medarbejdere. Og dette åbnede op for en legitimering af fagligheden. F.eks. blev medarbejdergruppen på prioriteringsworkshoppen bedt om at inddele deres opgaver i henholdsvis 'kan-opgaver' og 'skal-opgaver'. I medarbejdernes diskussion af prioritering af opgaverne blev der både delt ideer fra gulvet, ligesom der opstod nye ideer til, hvorledes arbejdsgange kunne forbedres. Her blev den faglige kreativitet overvejende søgt aktiveret inden for rammerne af de eksisterende systemkrav.

At formulere en idéskabende, innovativ ledelsesstrategi kan ifølge et systemteoretisk perspektiv ske ved at sætte fokus på de paradokser, som kan observeres i kommunikationen om f.eks. den gode omsorg. Vi har set, at diskussionerne gennemgående var præget af modstridende fordringer. Systemteorien antager, at sådanne paradokser ikke blot kan elimineres, men snarere ligger som indbyggede 'drivere' i kommunikationen. Der er således ikke blot tale om spændinger mellem ledelseslogikker og professionelles faglogikker, som man håber at fjerne eller anskuer som affødt af urimelige krav fra omverdenen. Udfordringen for frontlederen er snarere at afsøge internt, hvordan paradokser og modsatrettede logikker kan bringes til at avle innovative dynamikker. I et ledelsesperspektiv kan paradokser gøres produktive, hvis de anerkendes som grundlæggende træk ved den måde, hvorpå organisationer kommunikativt fungerer (Majgaard 2009). Ledere kan søge at reformulere paradokser ved, at hver side af paradoksets forskel udvides med nye betydninger, forskydes og hermed måske kan synliggøre nye handlemuligheder.

Den moderne leder af velfærdsproduktion må på mere end én måde være en mediator i en polyfon kontekst (Villadsen $2008,71)$. Ikke blot skal lederen sørge for at arbejdet bliver udført efter gældende krav, lederen skal også være opmærksom på symptomer på regeloverfortolkning, grænsesættende og konfliktskabende kommunikation samt dannelsen af selv-omsluttede grupper og enheder. Såfremt lederen for- 
mår at indtænke disse kommunikationsbetingelser i sin ledelse, er der mulighed for at sikre en løbende udfoldelse og udvikling af medarbejdernes faglighed, der i høj grad udspringer fra det daglige omsorgsarbejde. Lederen skal med andre ord søge at samordne sit behov for at håndtere polyfonien af krav med medarbejdernes behov for at være faglige. Rennison betegner dette som et polygamt lederskab, som er nødvendigt for en moderne velfærdsinstitution, "fordi kompleksiteten i opgavevaretagelsen fordrer mange partnere med hvert sit speciale og hver sin indsats" (Rennison 2014, 9-11).

\section{Konklusion}

I denne artikel stillede vi spørgsmålet: Hvordan påvirker det medarbejdere og ledere i velfærdsproduktionens udførende led, når kompleksiteten af svært forenelige fordringer intensiveres? $\mathrm{Vi}$ observerede, hvordan påtrængende økonomiske hensyn og reguleringsmæssige tiltag af retslig karakter blev fortolket som fremmed for omsorgen i medarbejdernes iagttagelse og installerede en følelse af mistillid. En gennemgående strategi til at reducere kompleksiteten af kommunikativ 'polyfoni' var for medarbejderne $\mathrm{i}$ feltet at lukke deres kommunikation omkring omsorgskoden. Hermed blev det muligt at drage slutninger som bl.a., at dokumentationskrav tager tid fra omsorgen og er udtryk for mistillid, at økonomiske nedskæringer betyder mindre tid til omsorg, og at regler betyder mindre plads til fagligt funderet omsorg. Medarbejderne kunne indikere sig selv som i opposition til det system, de er en del af.

En anden central iagttagelse var, hvad vi betegnede som 'regeloverfortolkning' iblandt hjemmeplejens medarbejdere og dennes rolle i medarbejdernes arbejde. Regeloverfortolkningen fungerede dels som en beskyttelsesstrategi, der skulle umulig- gøre beskyldninger om ukorrekt opgaveløsning, dels fungerede det som en indikation af den rigide og indskrænkende regelstyring af omsorgen. I sidste tilfælde opdagede vi, hvordan 'civil ulydighed' anvendtes som et modbegreb til regelstyringen. Flere af frontlederne kendte dette begreb og havde en fornemmelse af de problematikker, der var på spil blandt medarbejderne, men manglede værktøjer til at tydeliggøre dem og åbne op for en dialog om løsninger og håndteringsstrategier.

Vi præsenterede herefter en række overvejelser over, hvilke former for ledelse, der er behov for i lyset af den kommunikative polyfoni og de modsætninger, vi havde iagttaget i hjemmeplejernes diskussion af deres arbejdsliv. Spørgsmålet var: Hvilke muligheder har frontlederne for at udvide handlingsrummet for sine medarbejdere uden at begive sig ud i brud på det retslige grundlag eller fravigelse af de budgetmæssige rammer? Vi foreslog, at der ligger et vigtigt potentiale i, at lederne får blik for 'tavse' håndteringsstrategier og arbejdsmåder og anerkender disse. En sådan inddragelse af medarbejdernes faglighed i form af bl.a. diskussioner af 'på gulvet' udviklede løsninger kræver naturligvis tillid. Vi observerede, hvordan konsulenten, der ledte ledelsesudviklingsforløbet, var i stand til at skabe et talerum, hvor strategier, som ikke før havde været diskuteret åbent pga. frygt for, at de kunne opfattes som regelbrud, kom op til fælles debat. Disse diskussioner pegede på et ledelsespotentiale i at 'genaktivere' fagligheden ved at muliggøre sådanne italesættelser. Såfremt det 'innovative guld', der ligger gemt i frontmedarbejdernes faglighed, kan graves frem, synes der større chance for, at den stigende kompleksitet i velfærdsproduktionen kan håndteres. På basis af dette case-studie er dette dog fortsat en arbejdshypotese, der fortjener mere omfattende undersøgelse i fremtidige studier af velfærdsledelse. 


\section{REFERENCER}

Andersen, Niels Åkerstrøm (2000): Politisk administration, i T. B. Dyrberg, A. D. Hansen $\&$ J. Torfing (red.): Diskursteorien på arbejde, Frederiksberg, Samfundslitteratur.

Andersen, Niels Åkerstrøm (2002): Polyfone organisationer, i Nordiske Organisasjonsstudier, 4, 2, 25-52.

Andersen, Niels Åkerstrøm (2008a): Velfærdsledelse: diagnoser og udfordringer, i C. Sløk $\&$ K. Villadsen (red.): Velfoerdsledelse - $i$ den selvstyrende velfoerdsstat, København, Hans Reitzels Forlag.

Andersen, Niels Åkerstrøm (2008b): The world as will and adaptation: The interdiscursive coupling of citizens' contracts, i Critical Discourse Studies, 5, 1, 75-89.

Andersen, Niels Åkerstrøm \& Asmund Born (2003): Shifters, i H. Højlund \& M. Knudsen (red.): Organiseret Kommunikation, Frederiksberg, Samfundslitteratur.

Dahl, Hanne Marlene (2012): Who can be against quality? A new story about homebased care: NPM and govermentality, i C. Björnsdottír \& G. Perkins (red.): Perspectives on care at home for older people, London, Routlegde.

Hildebrandt, Steen (2013): Efter New Public Management, i MM Blog 14.05, Mandag Morgens hjemmeside: https://www.mm.dk/ blog/efter-new-public-management

Jensen, Annette (2009): Udfordring - velfærdsledelse skal praktiseres, i FOA, CBS, UCC: Velfaerdsledelse. 6 indloeg om offentlig ledelse, København, FOAs trykkeri.

Jensen, Signe Mie (2012): Velfoerdsledelse under pres - rapport fra hjemmeplejen, speciale ved cand.soc., Frederiksberg, CBS.

Kristiansen, Søren \& Hanne Kathrine Krogstrup (1999): Observationsmetoden og dens former, i Deltagende observation - introduktion til en forskningsmetodik, København, Hans Reitzels forlag.

Kristensen, Dennis (2010): Velfærdslederen i fokus, i FOA, CBS, UCC, KL: Voerdfoerdsledelse - det handler om praksis. Syv indloeg om offentlig ledelse, København, FOAs trykkeri.
Lipsky, W. (2010): Street Level Bureaucracy: Dilemmas of the individual in public services, New York, Russell Sage Foundation.

Luhmann, Niklas (1977): Differentiation of society, i Canadian Journal of Sociology, 2, 1, 29-53.

Luhmann, Niklas (1993): Observing Re-Entries, i Graduate Faculty Philosophy Journal, 16, 2, 485-498.

Majgaard, Klaus (2009): Slip paradokserne løs!, i Økonomistyring \& Informatik, 3, 24, 261302.

Mandag Morgen, Aarhus Kommune (2013): Kærlig Kommune - fremtidens sundhed og omsorg, i Aarhus, i Mandag Morgen Innovation ApS, København.

Moe, Sverre (1998): Den moderne hjelpens sociologi - velferd i systemteoretisk perspektiv, Oslo, Apeiros forlag.

Rennison, Bettina (2014): De fire lederskaber, $\mathrm{i}$ F.B. Andersen (red.): Ledelse af ledelse - anden ordens ledelse i organisationer, VIA Systime (under udgivelse).

Pedersen, Dorthe (2008): Strukturreformens styringspolitik - en overskridende dynamik, i D. Pedersen, C. Greve \& H. Højlund (red.): Genopfindelsen af den offentlige sektor - ledelsesudfordringer i reformernes tegn, København, Børsens Forlag.

Pedersen, Dorthe \& Hatley, Jean (2008): The Changing context of public leadership and management - implications for roles and dynamic, i International Journal of Public Sector Management, 21, 4, 327-339.

Seidl, David \& Kai Helge Becker (2006): Organizations as Distinction Generating and Processing Systems: Niklas Luhmann's Contribution to Organization Studies, i Organization, 13, 1, 9-35.

Thygesen, Niels Thyge (2009): Udfordring - når man skal udvikle teori om velfærdsledelse, i FOA, CBS, UCC: Velfoerdsledelse. 6 indloeg om offentlig ledelse, København, FOAs trykkeri.

Tønder Kommunes Social- og Sundhedsforvaltning (2011): Kvalitetsstandarder for personlig pleje og praktisk hjoelp, Tønder Kommune, 
http://www.swiflet.com/tk/aeogh/30/1/, hentet den 17.2.2014.

Villadsen, Kaspar (2011): Ambigious Citizenship: 'Modern' and 'postmodern' welfare at the margins, i Distinktion: Scandinavian
Journal of Social Theory, 12, 3, 309-329. Villadsen, K. (2008): 'Polyphonic' Welfare: Luhmann's systems theory applied to modern social work, i International Journal of Social Welfare, 1, 17, 65-73.

Signe Mie Jensen, cand.soc., Politisk Kommunikation \& Ledelse e-mail: signemie@gmail.com

Kaspar Villadsen, ph.d., lektor, Department of Management, Politics and Philosophy, Copenhagen Business School

e-mail: kv.mpp@cbs.dk 